\title{
Chitin-Based Biomonitoring: USE Living ArThropods OR CARRY SAMPLERS BY ROVS?
}

\author{
Stefan Fränzle \\ Technische Universität Dresden (TUD), Internationales Hochschulinstitut Zittau, \\ Deptm. of Bio- and Environmental Sciences, \\ Markt 23, D-02763 Zittau, FR Germany \\ e-mail: stefan.fraenzle@ @u-dresden.de
}

\begin{abstract}
Chitin which is located at outer surface of arthropods and some other organisms adsorbs quite a variety of possible environmental pollutants such as heavy-metal ions and-complexes and biomethylation products; thus biomonitoring is feasible without passing (and thus probably fractionating) analytes through metabolism. Isolated (from crab peeling) and grafted, chitin likewise acts as a sorbent, even in conditions which a living animal would not endure. Techniques originally developed in the author's lab to maintain animal integrity throughout sampling protocols are now used for analytical workup omitting sample digestion. Hazardous or poorly accessible sites may be investigated using ROVs which deploy chitin samples to the site for the $10 \mathrm{~min}$ until adsorption is usually completed.
\end{abstract}

\section{Keywords}

Chitin; Environmental sampling by adsorption; Biopolymer solutions; Analytical workup omitting sample digestion; Addressing hazardous sites by purposely designed ROVs.

\section{Introduction}

The previously established, e.g., [12], [13], [14], [15], use of native arthropod chitin (rather than [hydrolyzed] chitosan) to withhold/extract "heavy metal" pollutants or neutral or cationic organics ([1], [3], [11]) from waste water or from solutions obtained by dissolving processed nuclear fuel rods etc. (containing ${ }^{106} \mathrm{Ru}-\mathrm{NO}$ complexes, ${ }^{90} \mathrm{Sr}$, radionuclides of $\mathrm{Ba}$, La, Ce, etc., [13]) was developed by the author and his team into a method of estimating element concentrations by a simple contact with different media/matrices, e.g., [7]. This does encompass rather diverse speciation forms; chemical activities of the analytes are measured rather than total concentrations. This also holds for chemically connected different phases (e.g. inundated sediment, water above).

An obvious application in environmental monitoring to be based on living arthropods was finally developed - which was in fact demonstrated in our (IHI Zittau) lab - to obtain this kind of information without harming or killing the animals ${ }^{1}$ [2]. This does permit the use of protected or rare arthropod species (which holds for most which are sufficiently large, except of millipedes). However, the range/severity of environmental pollution living arthropods of sufficient size can both endure; and thus sample by either outer (i.e., chitin) covers or internal organs (muscles, fat, hemolymph (cp. [9]) is limited. Hence we switched to using isolated

\footnotetext{
${ }^{1}$ Whereas chitin also is produced by fungi, some bacteria and even certain vertebrates (blenniid fishes, forming their fin fortifications, [17]), the focus here is on arthropods (insects, spiders, isopods, millipedes etc.) as only in these organisms - not in fungi (which are no animals at all) nor in fishes or bacteria - chitin actually forms interfaces directly exposed to the environment
} 
chitin grafted on glass slides and we are currently developing devices for location of samples without humans being directly involved in sampling, thus enabling safe studies of hazardous imminent disaster sites, active volcanoes and their vents or in the deep ocean.

\section{$1 \quad$ Materials and Methods}

- Living field crickets (Gryllus assimilis) (obtained from a local pet shop, intended as food for reptiles, spiders, large fishes, etc.),

- Chitin flakes from peeled marine crab Pandalus borealis (Sigma-Aldrich), checked for background levels of many metals in our lab by digestion, ICP-MS,

- Metal-free glue to be photohardened by violet or UV light to attach chitin to glass slides or other supports (Solacor ${ }^{\mathrm{TM}}$ ),

- Dimethyl formamide $99.8 \%$, water-free, certified for trace metal contents (SigmaAldrich),

- Lithium perchlorate anhydrous, "battery-grade", certified for trace metal contents (Sigma-Aldrich),

- Strongly acidic cation exchanger Amberlite H-120, either employed in its native state or pre-treated by

- tris-n-butyl amine (both Sigma-Aldrich),

- dilute (1\%) nitric acid (Merck Suprapur ${ }^{\mathrm{TM}}$, diluted with deionized water),

- several salts and minerals representing more or less insoluble forms of chemical elements such as $\mathrm{Be}, \mathrm{Al}, \mathrm{Pb}, \mathrm{Mn}, \mathrm{Fe}, \mathrm{Co}, \mathrm{Cu}, \mathrm{Zn}, \mathrm{Cd}, \mathrm{Pb}, \mathrm{REEs}$, like beryl, Schalenblende (a layered $\mathrm{Zn} / \mathrm{Cd}$ - and $\mathrm{Fe} / \mathrm{Pb}$ sulfide from Poland), chalcopyrite, $\mathrm{La} 2 \mathrm{O} 3, \mathrm{LaCoSr}$ ferrite, mixed (Ce, REE') oxides or anhydrous $\mathrm{CoCl} 2$ (diverse mineral vendors, Sigma-Aldrich),

- microscope glass slides,

- nylon ${ }^{\mathrm{TM}}$ mesh bags for keeping mixed sample arrays (Fig.1) or retaining the ion exchanger resin.

Besides the data reported by vendors, all the items were analyzed for metal contents in this lab too. 


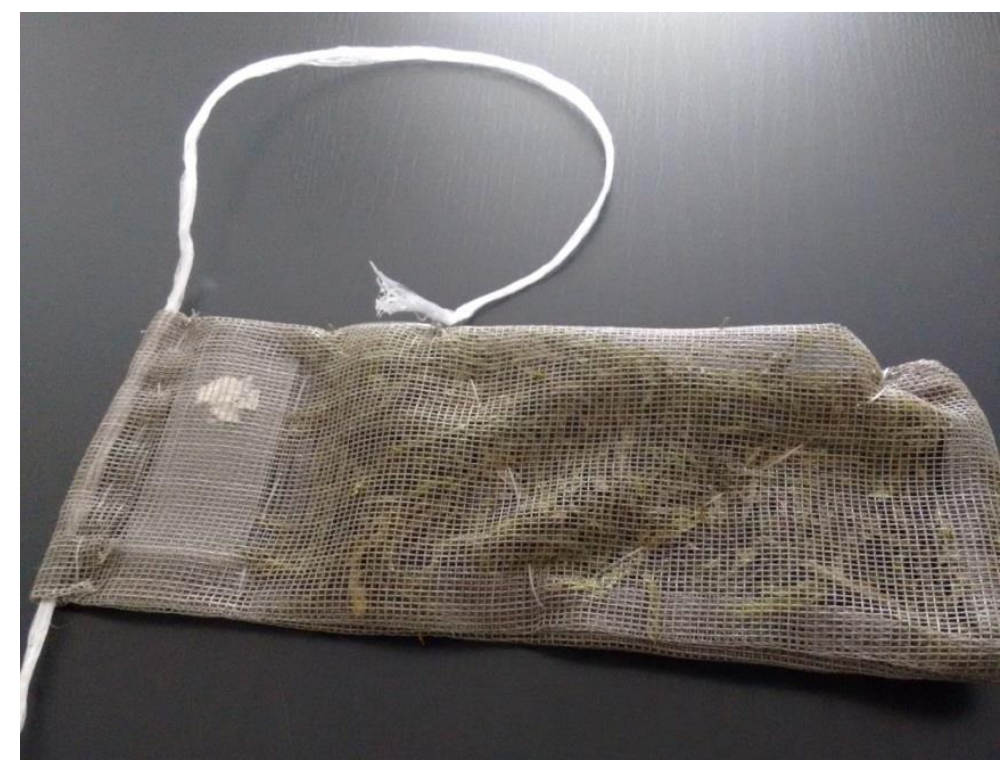

Source: Photo courtesy of G. Kosior, Poland 2015

Fig. 1: A mesh bag containing dried (thermally devitalized) aquatic moss (right, green) and a glass slide partly covered by chitin (left) for comparative studies of metal retention. Whereas lab experiments showed that adsorption was essentially completed to equilibrium within 10 min except for very high levels of humic acids, these assemblies were exposed to water (a mountain creek in Poland) for periods up to 15 days, assuring constancy of metal levels measured except for two cases of ongoing photochemical deposition $(U, A g)$ and surface decomposition upon the longest expositions.

\section{$2 \quad$ Properties of Chitin}

Chitin retains a couple of quite different chemical species to which it is exposed from either gas-, aq., organic solvent- or solid phases ([13], [14], [1], [2], [3], Schieritz \& Fränzle 2014, unpublished work). Experiments on vertical migration of adsorbed metals into the deeper chitin layers showed [8] that in some divalent cations $(\mathrm{Cu}, \mathrm{Ni}, \mathrm{Pb})$ substantial parts of total analyte inventory are retained in the uppermost, probably air-oxidized $2 \mu \mathrm{m}$-layer of chitin, with only the remainder passing on to form a more or less distinctive diffusion front whereas most make their way to deeper layers of chitin completely. Primary investigations on crab chitin from Pandalus borealis showed that except for Al, Fe and Ti background levels ${ }^{2}$ of chitin used were very low, owing to the minute solubilities of most "heavy metals" other than $\mathrm{Mo}, \mathrm{Cr}$ in conditions of oxygenated sea water $(\mathrm{pH}=8.2)$. This improves the possible sensitivity of detection of the very analytes in environmental samples.

\footnotetext{
${ }^{2}$ Levels of As detected in such environmental samples from quite diverse sites in Mongolia suggest a fairly highly As pollution (Fränzle et al., to be published); whereas quaternary arsonium salts such as arsenobetaine or tertiary arsine oxides are quite typical in marine crustaceans [10], the actual As background in the employed chitin is very low.
} 


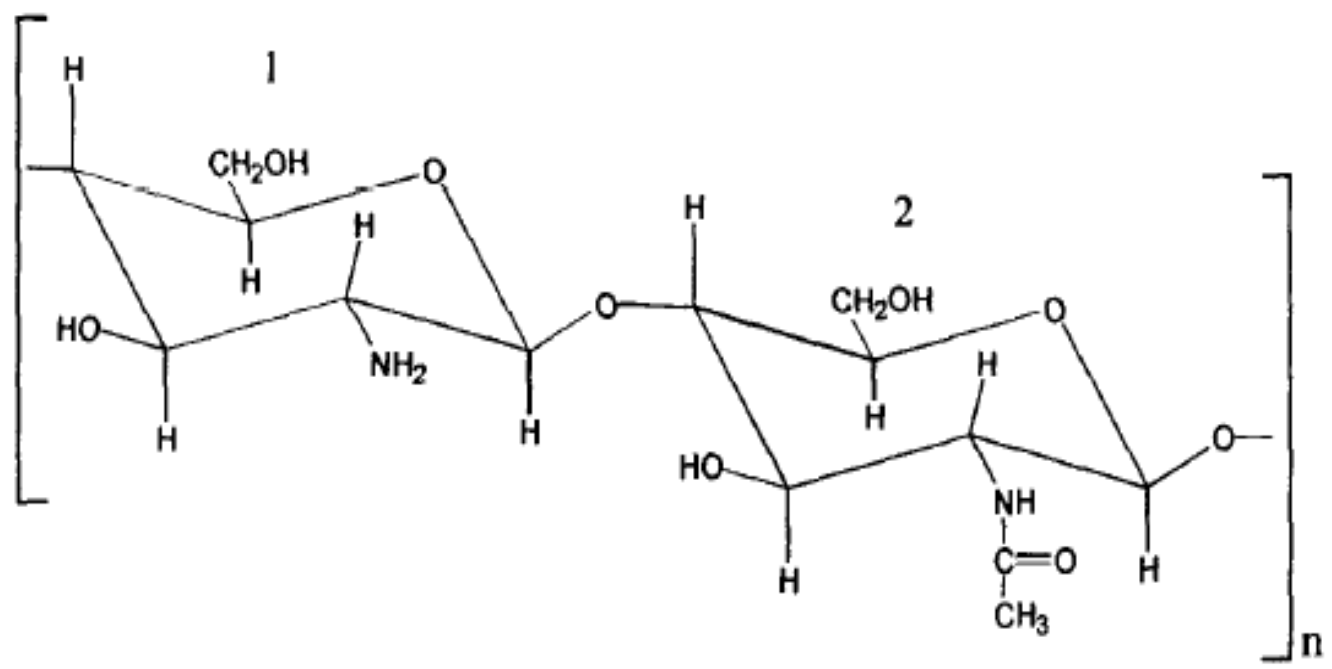

Source: [16]

Fig. 2: Structure of chitin

Source: [7]

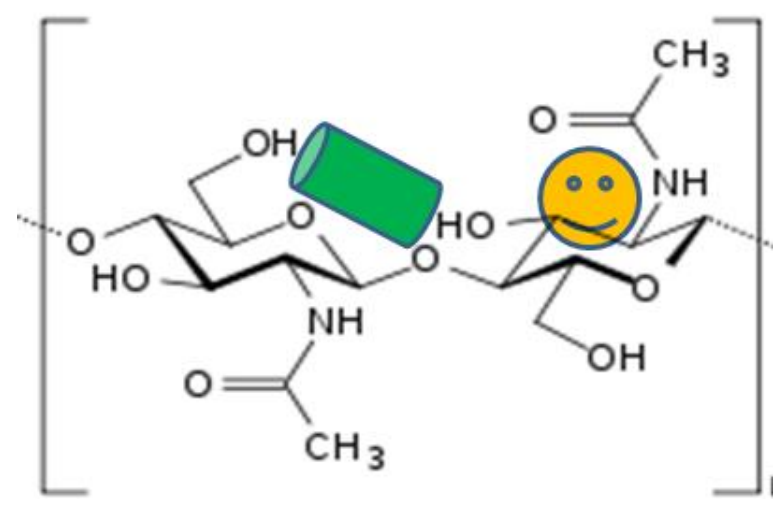

Fig. 3: Probable binding sites and-modes of metal cations (orange sphere) and H-bonding anions (green cylinder, meant to symbolize e.g. cyanide). Complexation to carboxamides mainly operates via $O$ rather than amide $N$.

Adsorption of organometal compounds like $\mathrm{Pn}\left(\mathrm{CH}_{3}\right)_{3}(\mathrm{Pn}=\mathrm{Sb}$ or $\mathrm{Bi})$ or homoleptic metal carbonyls $(\mathrm{M}=\mathrm{fe}, \mathrm{Mo}$, or $\mathrm{W})$ which both occur in landfill and sewage gases ([5], [6]) was investigated, including additions of oxidants like iodine or $\mathrm{O}_{2} / \mathrm{Co}$ (II)amino acid complexcombinations (which modify [likely enhance] binding properties by formation of oxospecies or of $\left[\mathrm{M}(\mathrm{CO})_{n} \mathrm{I}_{\mathrm{x}}\right]^{+}$or $\mathrm{Me}_{3} \mathrm{PnI}^{+}$ions, to understand the effects of oxygenation by soilborne exoperoxygenases produced by fungi and bacteria. However, corresponding effects were not observed unless for unrealistically high substrate levels (Schieritz \& Fränzle 2014, unpublished work). Preliminary data indicate that with $\left[\mathrm{Mo}(\mathrm{CO})_{6}\right]$ saturation is reached at about the level detected in landfill gases $(\approx 1 \mathrm{ppbv}$, see [5]). Substantial parts of it can be thermally desorbed in a headspace system and retrieved/identified in a GC/MS setup.

\section{Obtaining Samples by Grafted Chitin and Processing Them}

The procedure of sampling was described elsewhere; thus we may restrict to some brief outline here:

After exposition of the chitin surface (bright spot in left part of Fig. 1) to water, air or wet sediment, a concentrated solution $(1.6 \mathrm{M} / \mathrm{kg})$ of $\mathrm{LiClO}_{4}$ in $\mathrm{DMF}$ is pipetted on the chitin surface (about $0.1 \mathrm{ml} / \mathrm{cm}^{2}$ of chitin), dissolving the uppermost layer in $\mathrm{DMF} / \mathrm{Li}^{+}$medium, but 
not possible metal-containing particles ${ }^{3}$ adhering to the surface. For multiple ablations, this procedure is repeated up to eight times providing almost planar dissolution of layers some 2 $\mu \mathrm{m}$ thick in each case [8] to pinpoint how deep certain metals have migrated by diffusion. But it is likewise feasible to take eight times this amount and remove some $15 \mu \mathrm{m}$ of chitin at once (T. Gebauer 2016, oral communication). Then the solution - still adhering to chitin - is exposed to a small bag containing a cation exchanger resin $(300 \mathrm{mg})$ for $45 \mathrm{~s}$ to absorb the metal ions from the metalated chitin solution. Either the polymeric arenesulfonate resin is applied in its native protonated form or after treatment by tributyl amine in $\mathrm{CH}_{3} \mathrm{OH}$, the tributylammonium form can be used. After fixation to ion exchanger, the bag is immersed into $1 \%$ nitric acid pumped through it by a syringe several times to unload the ion exchanger. Additionally, this procedure will release metal ions still adhering to chitin as binding to the polymer stops at $\mathrm{pH}<<3$.

\section{$4 \quad$ Results}

Large sets of data already or to be published elsewhere ([8], Fränzle, Kosior et al. 2017) show that very different analytical items can be transferred/retrieved from different kinds of fluid or solid matrices by contact of moist solid or aq. slurry/suspension. Respective solid matrices include wood and minerals. Some 10 min-periods of mechanical contact with solids (cardpaper previously exposed to metal-containing components of dyes, fortifying additives [clays delivering Al], wood) suffice to produce a clear and lasting chemical signature in chitin surfaces ([2], [8]) which additionally permits to reconstruct the history of previous exposition of test animals (crickets, wood-wasps or beetles developing or living in wood) during rearing to a considerable number of elements, often including different speciation forms.

The approximate date when this (last) exposition took place can be reconstructed by following the slow vertical diffusion from the interacting surface to deeper layers. These can be dissolved one by one (each some $2 \mu \mathrm{m}$ ) removing almost plane layers and then analyzed in order to determine the extent of migration which, of course, increases with time while for $\mathrm{M}=$ $\mathrm{Ni}, \mathrm{Cu}$ or $\mathrm{Pb}$ a substantial part of total sorbate remains next to the surface even months after exposition, with only the remaining $30-55 \%$ migrating into "bulk" chitin. In lower layers, several elements, most pronounced $\mathrm{Co}\left(\mathrm{Co}^{2+}\right), \mathrm{Mn}$ and $\mathrm{Pb}$, produce diffusion fronts as clear maxima after several months of sample storage while levels of elements forming oxoanions like As, Mo tend to steadily decrease when changing into deeper layers. This also holds for organometals present in landfill vent gases (or others, such as volatile [e.g. Fe(III), Al, Sb] chlorides and metal carbonyls, in volcano/fumarole vents); recovery rates were studied in two different setups. Except for REEs, recovery rates measured using perchlorates, chlorides or para-toluene sulfonates of the respective elements added as DMF solutions to a previously non-metalized chitin solution in $\mathrm{DMF} / \mathrm{LiClO}_{4}$ will be higher and scatter (RSD) in data much smaller when using the $\mathrm{Bu}_{3} \mathrm{NH}$-modified resin.

Thus, this latter method is selected for actual environmental monitoring even though retrieval is smaller than with the original $\mathrm{H}^{+}$form for REEs ([4], [8], Fränzle et al. 2016); among the various REEs so far studied in lab experiments which revealed competition and fractionation from mixed oxides in favor of heavier, smaller-ion REEs (Sm, Gd vs. La, Ce) only Ce, for its

\footnotetext{
${ }^{3}$ As a rule, metal salts other than perchlorates, chlorides, acetates or trifluoromethanesulfonates will not dissolve in DMF, hence mineral dusts adhering to chitin flakes are not attacked. This improves resistance towards contamination of the sample during (concerning sediment samples) or after (air or water samples during retrieval and transport) sampling. Nevertheless, we plan to switch to processing the samples to this spot (transfer to ion exchanger or nitric acid) right at the place to exclude a) posterior contamination and b) vertical diffusion of certain (most) analytes within the chitin layers. The latter process would compromise sampling when only a single thin surface layer is removed.
} 
being reasonably abundant in common soil samples, has been studied in our environmental samples so far. In DMF/Li ${ }^{+}$solutions of chitin citrate can cleave complexation of Ce (but not trivalent $\mathrm{Sm}, \mathrm{Eu}$, or $\mathrm{Yb}$ ) to chitin, agreeing with studies of ligands effects observed in chitinbased extraction of mixed REE-, LaSrCoFe- and Ni/REE oxides with ligand-free ${ }^{4}$ and loaded aq. chitin suspensions. Back-exchange using dilute aqueous acid will recover the metal ions and render them in a form useful for ICP-MS- or ICP-OES analysis.

\subsection{Sorption and Photosorption}

By and large, sorption equilibrium is reached within 10 min, except if there are high levels of humic acids, whereas other ligands to be found in soil liquids or forest waters do not influence either the maximum amount to be bound or the kinetics. Upon prolonged exposition, uranium (probably $\mathrm{UO}_{2}{ }^{2+}$ ) and $\mathrm{Ag}^{+}$are adsorbed much beyond primary equilibrium, given that there is light shining on the chitin samples. This indicates photochemical deposition of either element, Ag probably as metal nanoparticles, uranium as $\mathrm{UO}_{2}$. Binding capacities of ground chitin are some $35-40 \mu \mathrm{M} / \mathrm{g} \mathrm{DM}$ for most di- and trivalent ions.

\subsection{Animal-Friendly Ways of Sampling: Implications for Selection of Possible Test Animals}

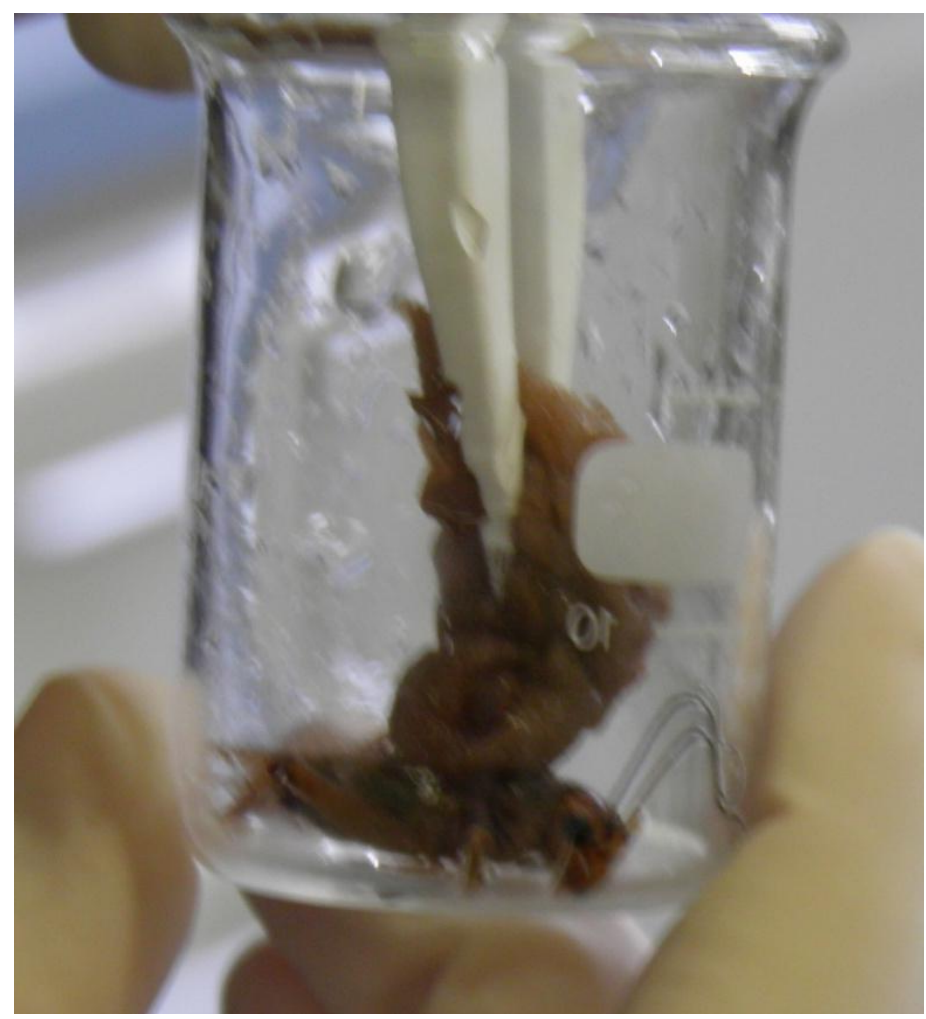

Source: Photo courtesy of A. Bauer 2013

Fig. 4: Time-zero check of a field cricket (Gryllus assimilis) by the method described in text

\footnotetext{
${ }^{4}$ The ligands selected (glycinate, citrate, hydroxamates, humic acids) and their concentrations were meant to simulate soil solutions under different kinds of vegetation.
} 


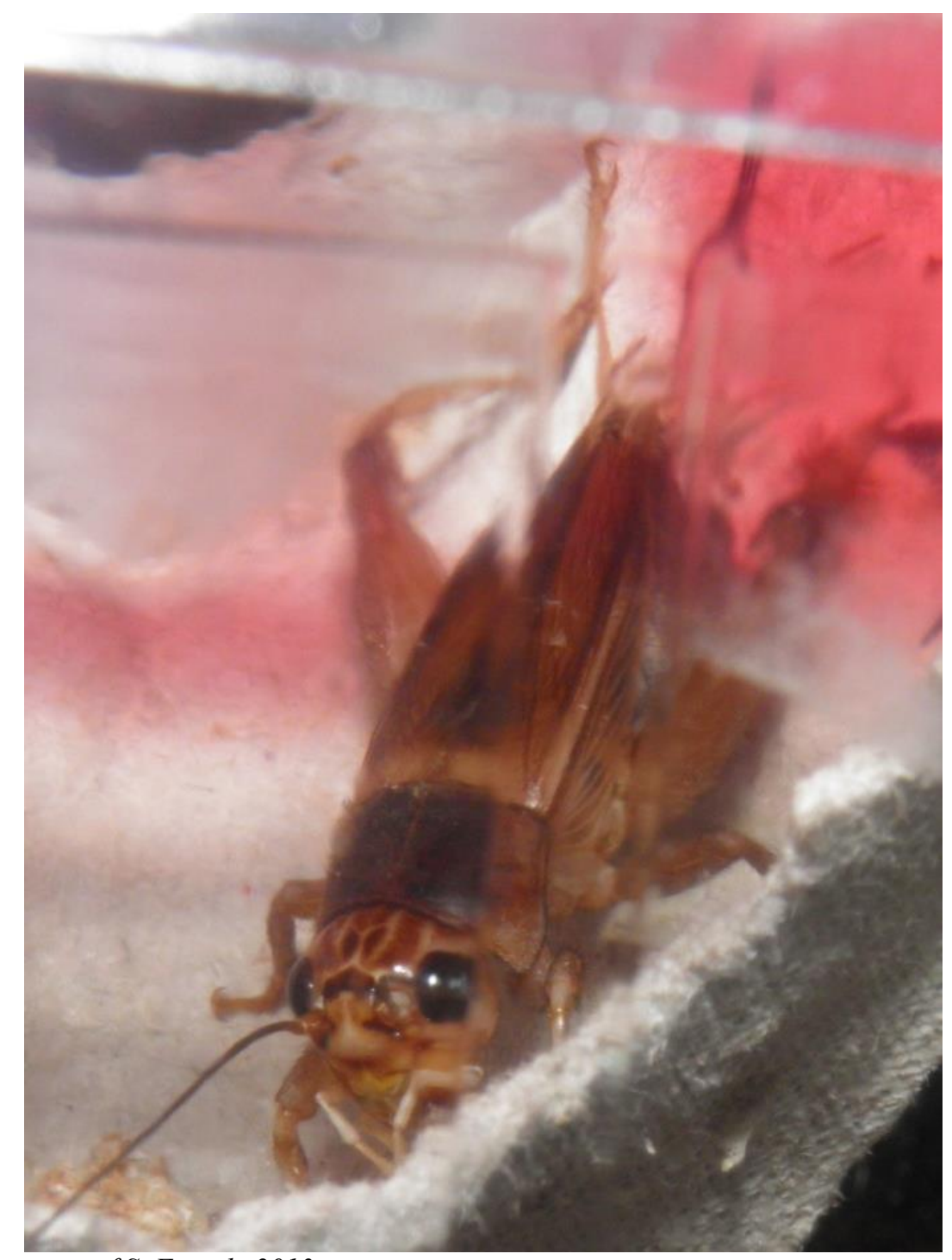

Source: Photo courtesy of S. Fränzle 2013

Fig. 5: Field cricket in a microterrarium dwelling on moist silica doped with metal salts or ground minerals at levels of several $100 \mu \mathrm{g} / \mathrm{g}$. The red color is due to photographic flash.

Just a thin layer of chitin is dissolved from the carapace without harming the animal ${ }^{5}$ which is reversibly immobilized by cooling to $\mathrm{T} \approx 0^{\circ} \mathrm{C}$. With the crickets, many specimens were observed moving with their lower abdomina in permanent contact with the model sediment consisting of silica powder for chromatographic purposes and ground minerals or insoluble salts added to it in concentrations selected to represent "Dutch List" intervention levels; these amounts could be readily identified. Although different crickets were observed to differ considerably in self-cleaning activities, the results would be highly reproducible.

\section{$5 \quad$ Discussion}

Living arthropods are versatile in chitin-based biomonitoring and can inhabit very diverse habitats and biocoenoses where neither plants (including mosses) nor vertebrates would persist for long or even reproduce. Yet, unless for very specific sites offering the only affluent nutrient sources around, like "black smokers" in the deep ocean, they are unlikely to keep

\footnotetext{
${ }^{5}$ At least if you (can) avoid getting the solvent into tracheae
} 
close to sites where there is some high load in analytes/pollutants; moreover, they might either flee from or succumb to (even if kept in cages, terrariums or tanks for limited, well-defined periods of time) high levels of pollutants. Accordingly, the most critical sites cannot be measured despite the fact that chitin is a most versatile sorbent. Hence, the author has changed his original attitude, shaped by biomonitoring concepts, towards using chitin samples attached to inorganic supports which can be freely placed almost regardless of local conditions far beyond those required for arthropod survival. Due to low background levels submarine freshwater springs (typically rich in Fe), "black smoker" sites could be detected and investigated in the same manner. By comparison among chitin attached to the outer surface of submersibles, an improved understanding of chemical transport supporting the local biocoenosis can be achieved, like in terrestrial and bog environments, then e.g. using airborne sampling devices (shown in Fig. 6 and 7).

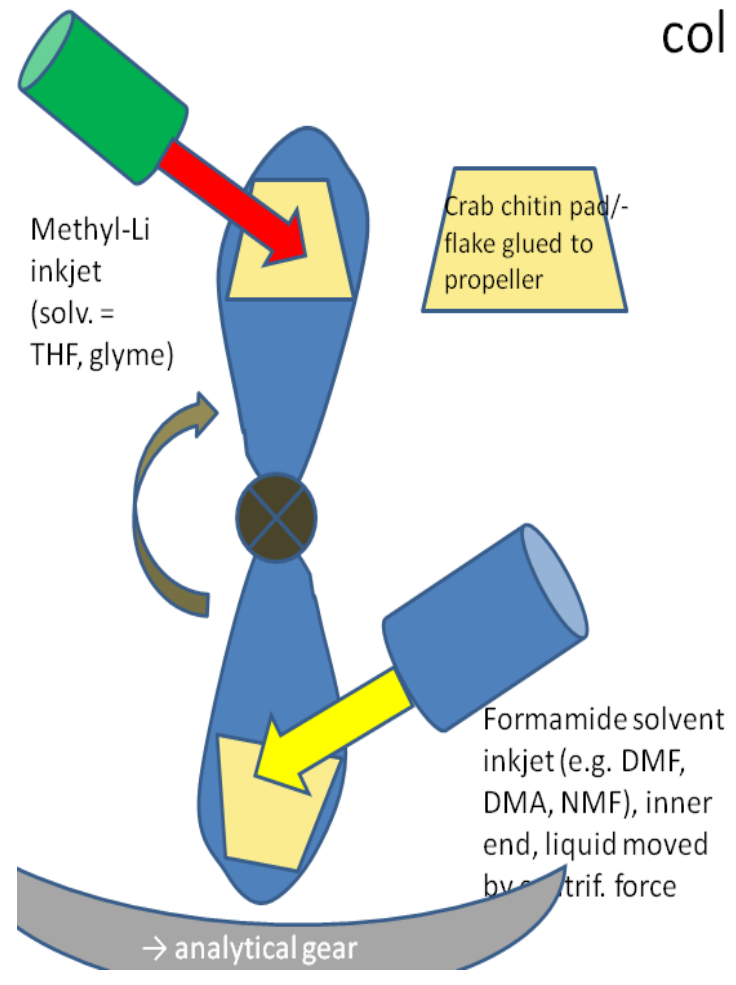

Source: Own

Fig. 6: Chitin sampling of components of fluids and a method for direct removal to sampling device. The grey curve (bottom) may represent a cation exchanger resin. After binding to the resin, back-elution is affected by 1\%-nitric acid and the sample is directly taken to ICP-MS.

\section{ROV Technologies to Dislocate Chitin for Sampling (Status and Outlook)}

Accepting grafted chitin to be superior in applicability and reproducibility of results to living, freely swimming or flying or crawling animals means one must design vehicles to get the sampling sheets to the area/sites to be investigated, usually ROVs for reasons soon to be described. The sampling device must remain at the spot just until equilibrium is reached $(\approx 10$ minutes), then withdrawing the sampler carrier and returning to the starting site or (more conveniently) moving to another sampling site within one mission. At the present state of technical development, remote control still must be considered superior to operating some fully autonomous systems, whether being airborne, moving on solid ground or water or being a submersible. Possible designs are shown here, one meant for sampling metal contents of leaf litter, topsoil, other soft sediments (penetrating into an anoxic submerged layer in a controlled 
fashion) and (shallow) water, while the other (fixed to some propeller) should bind analytes from air or water directly.

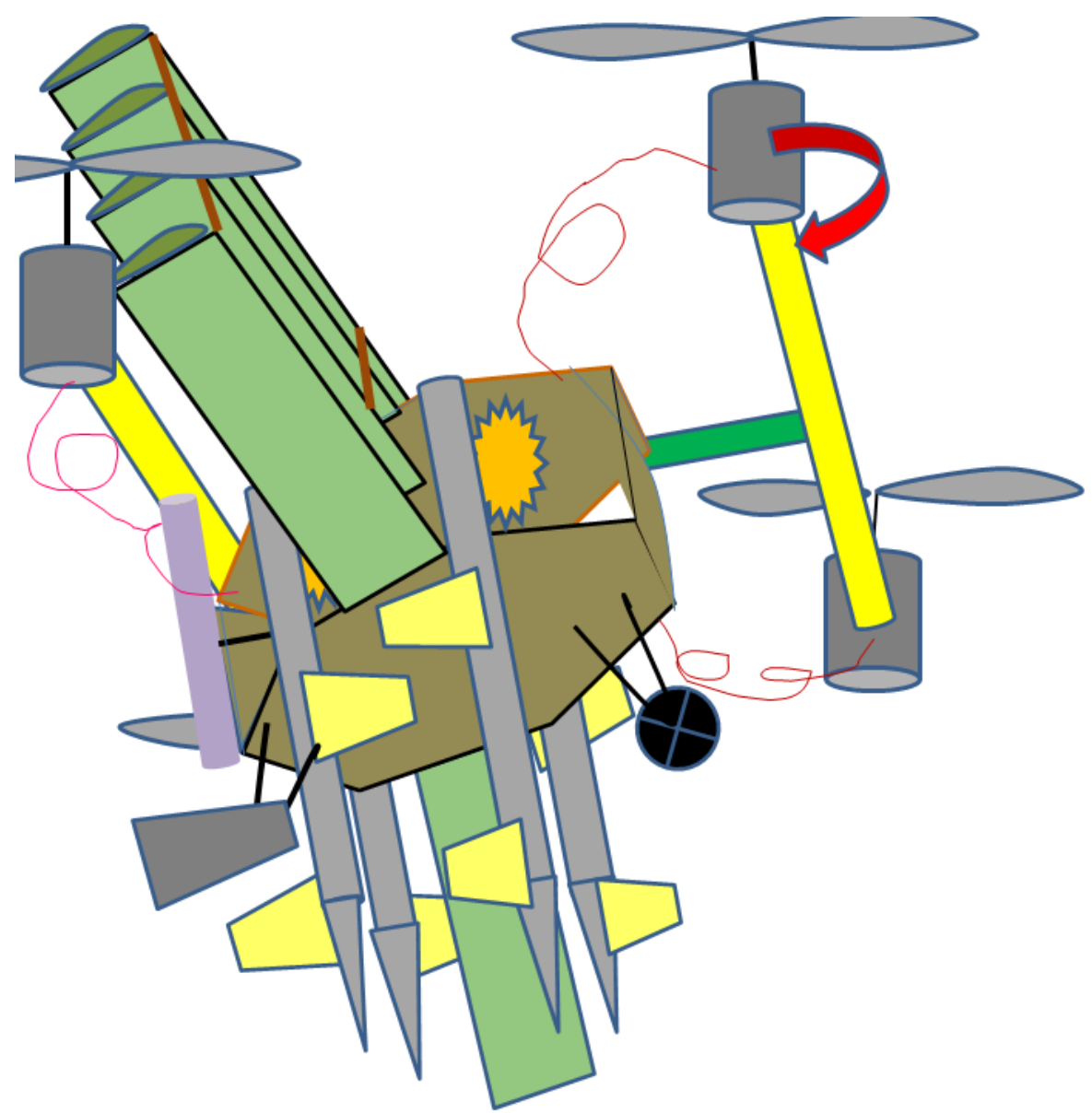

Modified quadro-
copter: by tilting all
four rotors, uplift for
vertical take-off is
produced whereas
changes of flight
direction depend on
applied power. Four
poles driven by tooth-
wheels (orange) poke
into water or soft
sediment $\rightarrow 4^{*} 2$
samples/flight
mission. Yellow:
grafted chitin

Source: Own

Fig. 7: A multicopter drone equipped with stacked wings for more efficient (slow) horizontal flight in between sampling sites. Chitin flakes are fixed to (covers of) retractable poles to be inserted into water or/and soft sediment one by one. Moving front wheels and aft ski towards each other assists re-take-off of plane. The device is kept at one sampling site for some 10 min until equilibrium of chitin adsorption is reached.

\section{Conclusion}

Chitin is a very useful and affordable ${ }^{6}$ sorbent material for purposes of environmental analysis. Comparative studies in rivers/creeks, their underlying sediments and mining sites in Mongolia showed, in full accord with the expectations and the fact that chitin does bind the metal ions by complexation and thus does probe their respective chemical potentials, that adsorption from water samples $(\mathrm{pH}=5.5-7.6)$ and underneath sediment give almost identical values in still or slowly running waters, with the highest $\mathrm{Al}$ readings over/in a clayey river bed (lower Tuul R.) and $\mathrm{Cu}$ maxima in runoff waters of a copper mine near Erdenet.

\section{Literature}

[1] AKKAYA, G.; UZUN, I.; GÜZEL, F.: Kinetics of the adsorption of reactive dyes of chitin. Dyes Pigm. 2007, Vol. 73, pp. 168-77.

\footnotetext{
${ }^{6}$ The otherwise most costly part of the sample analytical procedure, that is sample digestion, is not necessary; a single test kit will buy just a few $€$-ct.
} 
[2] BAUER, A.: Master thesis; IHI Zittau, 2014.

[3] CRISAFUlly, R.; MILHOME, M. A.; CAVALCANTE, R. M.; SILVEIRA, E. R.; De KEUKELEIRE, D.; NASCIMENTO, R. F.: Removal of some polycyclic aromatic haydrocarbons from petrochemical wastewater using low-cost adsorbents of natural origin. Bioresour Technol. 2008, Vol. 99, pp. 4515-4518.

[4] ERLER, M.: Bachelor thesis; Univ. of Applied Sciences Zittau/Görlitz, 2016.

[5] FELDMANN, J.: Determination of $\mathrm{Ni}(\mathrm{CO})_{4}, \mathrm{Fe}(\mathrm{CO})_{5}, \mathrm{Mo}(\mathrm{CO})_{6}$, and $\mathrm{W}(\mathrm{CO})_{6}$ in sewage gas by using cryotrapping gas chromatography inductively coupled plasma mass spectrometry. J Environ Monit. 1999, Vol. 1, pp. 33-37.

[6] FELDMANN, J.; CULLEN, W. R.: Occurrence of volatile transition compounds in landfill gas: Synthesis of molybdenum and tungsten carbonyls in the environment. Environ Sci Technol. 1997, Vol. 31, pp. 2125-2129.

[7] FRÄNZLE, S.: Adsorption to chitin - a viable and organism-protecting method for biomonitoring metals present in different environmental compartments getting contacted with arthropods. Annali di Botanica. 2015, Vol. 148, pp. 413-422.

[8] GEBAUER, T.: Master thesis; IHI Zittau, 2016.

[9] HOPKIN, S. P.: Ecophysiology of Metals in terrestrial Invertebrates. Elsevier, London and New York, 1989.

[10] IRGOLIC, K. J.: Arsenic in the environment. In: Xavier, A. V. (ed.): Frontiers in bioinorganic Chemistry. 1986, VCH, Weinheim.

[11] MILHOME, M. A. L.; De KEUKELEIRE, D.; RIBEIRO, J. P.; NASCIMENTO, R. F.; CARVALHO, T. V.; QUEIROZ, D. C.: Removal of phenol and conventional pollutants from aqueous affluent by chitosan and chitin. Quimica Nova. 2009, Vol. 32, No. 8.

[12] MOATTAR, F.; HAYERIPOUR, S.: Application of chitin and zeolite absorbents for treatment of low level radioactive wastes. Intern J Environ Sci Tech. 2004, Vol. 1, pp. $45-50$.

[13] MUZZARELLI, R. A. A.: Uptake of nitrosyl 106-Ruthenium on chitin and chitosan from waste solutions and polluted seawater. Wat Res. 1970, Vol. 4, pp. 451-455.

[14] MUZZARELli, R. A. A.: Natural Chelating Polymers. Pergamon, New York, 1973.

[15] PINTO, P. X.; AL-ABED, S. R.; REISMAN, D. J.: Biosorption of heavy metals from mining-influenced water onto chitin products. Chem Engin J. 2011, Vol. 166, pp. 10021009.

[16] P'LISKO, E. A.; NUD'GA, L. A.; DANILOV, S. N.: Chitin and its chemical transformations. Russ Chem Rev. 1977, Vol. 46, pp. 1470-1487.

[17] WAGNER, G. P.; LO, J.; LAINE, R.; ALMEDER, M.: Chitin in the epidermal cuticle of a vertebrate (Paralipophrys trigloides, Blenniidae, Teleostei). Experientia. 1993, Vol. 49, pp. 317-319.

Dr. Stefan Fränzle 


\section{BIOMONITORING NA ZÁKLADĚ CHITINU: POUŽÍT ŽIVÉ ČLENOVCE NEBO ZKOUMAT VZORKY POMOCÍ ROV?}

Chitin, který se nachází na vnějším povrchu členovců a některých dalších organismů, absorbuje poměrně širokou škálu látek znečištujících životní prostředí, jako jsou tě̌̌ké kovy, komplexní sloučeniny iontů a produkty biometylace. Biomonitoring je tudíž proveditelný, aniž by procházel (a tedy pravděpodobně frakcionoval) analyty prostřednictvím metabolismu. Izolovaný (odlupováním korýšů) a roubovaný chitin rovněž působí jako sorbent, a to i v podmínkách, ve kterých by živá zviŕăata nepřě̌ila. Techniky, které byly původně vyvinuté $\mathrm{v}$ autorově laboratoři $\mathrm{s}$ cílem zachovat integritu zvířat $\mathrm{v}$ rámci dodržování protokolů pro odběr vzorků, jsou nyní používány pro analytické zpracování, aniž by vzorky byly louhovány. Nebezpečná nebo špatně príistupná místa mohou být zkoumány pomocí ROV. Vzorky chitinu je tak možno zanechat na místě, dokud - po zhruba 10 minutách - nedojde k ukončení absorpce.

\section{AUF CHITIN BASIERENDES BIOMONITORING - VERWENDUNG LEBENDER GLIEDERFÜßER ODER DIE ERFORSCHUNG DER PROBEN MIT HILFE VON ROV?}

Chitin, das die äußere Oberfläche von Arthropoden sowie mancher anderer Organismen bildet, adsorbiert eine Vielfalt potenzieller Umweltschadstoffe, darunter Schwermetall-Ionen und -komplexe sowie Biomethylierungsprodukte, was Biomonitoring ohne vorausgehende Fraktionierung im Stoffwechsel ermöglicht. Isoliertes (aus marinen Krabben) und trägerfixiertes Chitin fungiert als Sorbens auch unter Bedingungen, die ein lebendes Tier nicht überstünde. Die Methoden, die im Labor des Autors entwickelt wurden zu dem Zweck, Versuchstiere auch bei mehrfacher Beprobung am Leben zu erhalten, dienen jetzt zur analytischen Bearbeitung. Schwer oder nur unter Gefahren zugängliche Standorte sollen künftig mit ROVs („Drohnen“, „Rover“), die an den Auslegern Chitinproben tragen, untersucht werden, wobei 10 Minuten am Messstandort für die Adsorption ausreichen.

\section{BIOMONITORING NA PODSTAWIE CHITYNY: ZASTOSOWANIE ŻYWYCH STAWONOGÓW LUB BADANIE PRÓBEK PRZ POMOCY ROV?}

Chityna, znajdująca się $\mathrm{w}$ zewnętrznej warstwie stawonogów i niektórych innych organizmów, pochłania stosunkowo dużą ilość substancji zanieczyszczających środowisko, takich jak metale ciężkie, kompleksowe związki jonów i produkty biometylacji. Biomonitoring może być więc przeprowadzony bez konieczności wykorzystania (czyli prawdopodobnie frakcjonowania) analitów w procesie metabolizmu. Także odizolowana (zdjęta ze skorupiaków) chityna działa jako pochłaniacz, zachowując te cechy także w warunkach, w których żywe organizmy by nie przetrwały. Techniki, które opracowano początkowo $\mathrm{w}$ laboratorium autora $\mathrm{w}$ celu zachowania integralności zwierząt $\mathrm{w}$ ramach przestrzegania protokołów pobrania próbek, stosowane są obecnie do obróbki analitycznej bez potrzeby namaczania próbek. Miejsca niebezpieczne lub trudno dostępne można badać przy pomocy ROV. Próbki chityny można dzięki temu pozostawić na miejscu, dopóki - po około 10 minutach - proces absorpcji się nie zakończy. 